\title{
21036 Elderly Exposure to Fungi: A Review Study
}

Marina Almeida-Silva, Polytechnic Institute of Lisbon, Lisbon, Portugal and University of Lisbon, Lisbon, Portugal

Cristiana Pereira, University of Porto Institute of Public Health, Porto, Portugal and National Institute of Health Doctor Ricardo Jorge, Porto, Portugal

(C) 2020 .

\section{Introduction}

Indoor air quality is an increasing concern since people spend $90 \%$ of their time indoor. The majority of exposure to air pollution happens indoors rather than outdoors, despite the focus being on the latter. Indoor air quality in elderly care centers (ECC) is an emerging important issue arising in the last decade because of the increase of (1) life expectancy, (2) number of individuals residing in ECC, and (3) population aging, which is correlated with the inversion of the age pyramid (United Nations UN, 2012; GEP/MSSS, 2010). However, given the magnitude of the ECC population that is ageing, and the considerable amount of time spent by elders within ECC, information linking contamination of ECC by particles, micro-organisms and exposure of elders continues to be sparse (Almeida-Silva et al. 2014a,b). Thus, societies must provide environments that guaranty the wellbeing of vulnerable groups like the elderly.

The older population is growing faster than the total population in practically all regions of the world - and the difference in growth rates is increasing (United Nations UN, 2012). Since 1996 until 2008 the number of adults aged $>65$ years increased $31 \%$ (from 380 million to 500 million). According to the United Nations UN (2013) the percentage of total population aged 60 years or over in the world was $11 \%$ for the year 2010 and is estimated to be $18 \%$ for 2050 . Although indoor concentration and number of carcinogenic air pollutants has been decreasing since the 1950s (Weschler, 2009), all of the previously evidences, plus the changes on life-style and the fact that people spend a large part of their life inside indoor environments have promoted an increase on exposure to indoor air pollutants (Byčenkiene et al., 2009; Zhao et al., 2009; Dales et al., 2008; Leech et al., 2002; Klepeis et al., 2001). Consequently, we are witnessing an intensification of studies developed by the scientific community concerning Indoor Air Quality (IAQ) and its effects upon health (Canha et al., 2012a,b; Franck et al., 2011; World Health Organization WHO, 2010; Saliba et al., 2009; Fraga et al., 2008; Fromme et al., 2007; Kosonen and Tan, 2004; Lee et al., 2002; Wilson, 1996; Allen and Miguel, 1995). Indoor air pollution is caused by a combination of several factors: hazardous substances that are emitted from the outdoors, buildings, construction materials, furnishings, equipment, inadequate ventilation, indoor human activities, etc. (Almeida-Silva et al., 2015; Canha et al., 2013; Viegas et al., 2010; Weschler, 2009). Physical factors such as air temperature, air velocity and relative humidity are usually used as indicators of thermal comfort, in IAQ studies. The main chemical and biological parameters used to characterize the IAQ are carbon monoxide $(\mathrm{CO})$ and dioxide $\left(\mathrm{CO}_{2}\right)$, the volatile organic compounds (VOC), the formaldehyde $\left(\mathrm{H}_{2} \mathrm{CO}\right)$, the ozone $\left(\mathrm{O}_{3}\right)$, the particulate matter $(\mathrm{PM})$, fungi and bacteria. Several studies positively correlated indoor exposure to microorganisms and microbial components with adverse health effects including headache and respiratory symptoms (Douwes et al., 2003). Considering specifically fungi, their spores are complex agents that may contain multiple hazardous components. Health hazards may differ across species because fungi may produce different allergens and mycotoxins. Moreover, some species also infect humans (Eduard and Halstensen, 2009). Most infections occur in immunocompromised hosts or as a secondary infection, following inhalation of fungal spores or the toxins produced by them (Srikanth et al., 2008). It is known that some people are sensitive to molds and exhibit symptoms such as dry nose, wheezing, and red or itchy eyes or skin when exposed to molds. Severe reactions have also been observed among workers exposed to large amounts of molds in occupational settings including fever and shortness of breath. Exposure to mold or dampness may also lead to development of asthma in some individuals (Centers for Disease Control and Prevention CDC, 2017).

\section{Methodology}

In order to identify the scientific publications to be included in this review and analysis, three search engines were used: Web of Science (WoS), Scopus, and Online Knowledge Library (b-on). This strategy allowed to access to the largest number of existing publications under this topic. These search engines were selected due to its interdisciplinary nature, in order to cover several disciplines - from mycology to environmental science.

The search methodology was developed under three steps.

\section{First Step}

The follow keywords were selected and search in all selected search engines:

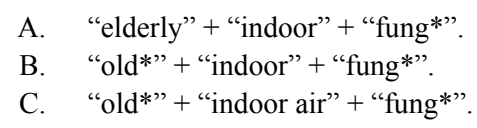




\section{Second Step}

After the first approach a list of inclusion and exclusion criteria was created, in order to do a deep and refined selection of the retrieved publications. Inclusive criteria: publications that studied indoor environments related to elderly people; publications in English and Portuguese. Exclusive criteria: publications before the year 2000; publications in duplicate; the follow keywords - "child*", "infant*" and "work". Table 1 presents the number of publications under the study in first and second methodological steps.

\section{Third Step}

A database with all selected articles was elaborated. During this process all duplicate publications were erased, as well as publications that didn't present any quantitative or qualitative data regarding fungi concentrations in elderly homes. The studies included in this integrative review were selected based on their content. In terms of content, each publication selected for this literature review included results based on empirical data on the relation between fungi concentrations assessed indoors and elderly or old people. Considering the purpose of this study, the possible influence of sociodemographic variables was not considered in this article, since it was considered irrelevant.

At the end, 11 publications (Table 2) were compiled to be discussed in the next sub-chapter.

\section{Results and Discussion}

Table 2 summarizes the selected publications after the application of the three methodological steps described previously.

The temporal distribution of the 11 publications identified according to the stated criteria was not uniformed. A total of $9 \%$ covered the period between 2005 and 2010; 27\% represented the period between 2010 and 2015; 64\% were from the period between 2015 and 2019. The largest proportion of studies identified in recent years, or in other words since 2015 , may be due to the fact that scientific

Table 1 Number of publications identified according to each keywords' group, search engine and inclusion and exclusion criteria

\begin{tabular}{|c|c|c|c|c|c|c|}
\hline Keywords & $A$ & & $B$ & & $C$ & \\
\hline Methodological Step & 1 & 2 & 1 & 2 & 1 & 2 \\
\hline WoS & 46 & 17 & $313^{\mathrm{a}}$ & - & 212 & 19 \\
\hline Scopus & 15 & 9 & 111 & 14 & 57 & 9 \\
\hline b-On & 22 & 11 & 96 & 15 & 47 & 10 \\
\hline
\end{tabular}

aDue to the big amount of generated data and the heterogeneity of the results this keywords' group for WoS was rejected.

Table 2 Selected publications after the three methodological steps




studies about indoor air pollutants in elderly care centers only effectively began in the second half of the 20th century, with scientific production on this theme intensifying from this period onwards.

The selected publications are from Europe (73\%) and Asia (27\%). Fig. 1 represents the general characterization of the selected publications according to the country in study. It is possible to observe that Portugal shows the highest percentage (55\%) of developed works on the studied field, followed by Asiatic Continent (Iran, Korea and China). This shows a Portuguese great concern about this topic and goes in line with the European society' evolution: (1) in 2014 the Portuguese ageing rate was higher that the European average, with $21 \%$ of the population aged 65 or over (Eurostat, 2014); (2) according to Eurostat, Portugal will have the oldest European population in 2050 , with almost $50 \%$ of the population with more than 55 years old. The justification is given by a historical drop in fertility rates, increased average life expectancy and, in some cases, migration patterns (Eurostat, 2019) (see Figure SI 1).

Regarding the methodology of each study it was possible to observe (Table 3$)$ that $63 \%(n=7)$ of the selected works used impaction as sampling method, either using the Merck Air Sampler MAS-100 ( $\mathrm{n}=4)$, the Six-stage cascade impactor (Andersen, Model 10-800) ( $\mathrm{n}$ = 1), the Merck Millipore M Air T $(n=1)$, or the Surface Air System air sampler $(n=1)$ (Table 2). Of those, 5 used malt extract agar

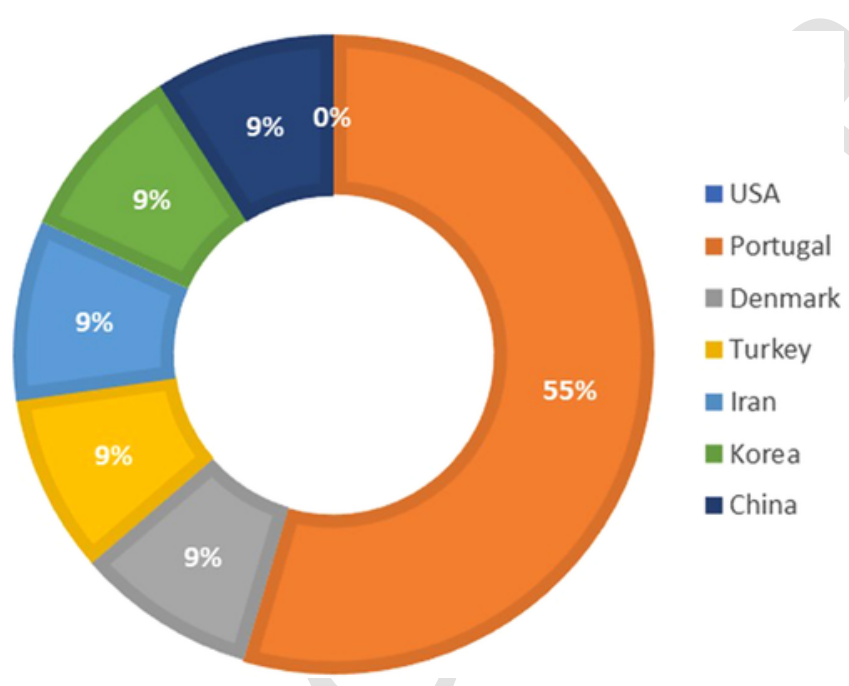

Fig. 1 Publications distributed according to its localization.

Table 3 Detailed information regarding the applied methodology

\begin{tabular}{|c|c|c|c|c|c|}
\hline Ref. & Indoor & Outdoor & Equipment & Agar & $\begin{array}{l}\text { Incubation conditions (duration } \\
\text { (days); temperature }\left({ }^{\circ} \mathrm{C}\right) \text { ) }\end{array}$ \\
\hline $\begin{array}{l}\text { (Kim and Kim, } \\
\text { 2007) }\end{array}$ & $\mathrm{x}$ & $\mathrm{x}$ & $\begin{array}{l}\text { Six-stage cascade impactor } \\
\quad \text { (Andersen, Model 10-800) }\end{array}$ & $\begin{array}{l}\text { MEA with } \\
\text { chloramphenicol }\end{array}$ & $3-5 \mathrm{~d} ; 20-25^{\circ} \mathrm{C}$ \\
\hline (Aguiar et al., 2014) & $\mathrm{x}$ & $\mathrm{x}$ & Merck Air Sampler MAS-100 & MEA & $3 \mathrm{~d} ; 25^{\circ} \mathrm{C}$ \\
\hline (Viegas et al., 2014) & $\mathrm{x}$ & $\mathrm{x}$ & Merck Air Sampler MAS-100 & $\begin{array}{l}\text { MEA with } \\
\text { chloramphenicol }\end{array}$ & $5-7 \mathrm{~d} ; 27^{\circ} \mathrm{C} \pm 2^{\circ} \mathrm{C}$ \\
\hline (Mendes et al., 2015) & $\mathrm{x}$ & $\mathrm{x}$ & Merck Air Sampler MAS-100 & MEA & $25^{\circ} \mathrm{C}$ \\
\hline $\begin{array}{l}\text { (Karottki } \text { et al., } \\
\text { 2015) }\end{array}$ & $\mathrm{x}$ & - & $\begin{array}{l}\text { Electrostatic Dust Cloths (for } \\
15 \text { days) }\end{array}$ & DG-18 & $3-7 \mathrm{~d} ; 25^{\circ} \mathrm{C}$ \\
\hline (Cano et al., 2016) & $\mathrm{x}$ & $\mathrm{x}$ & Merck Air Sampler MAS-100 & MEA & $4-5 \mathrm{~d} ; 25^{\circ} \mathrm{C}$ \\
\hline (Mendes et al., 2016) & $\mathrm{x}$ & $\mathrm{x}$ & $\mathrm{n} / \mathrm{d}$ & $\mathrm{n} / \mathrm{d}$ & $\mathrm{n} / \mathrm{d}$ \\
\hline (Yilmaz et al., 2017) & $\mathrm{x}$ & $\mathrm{x}$ & Merck Millipore M Air T & $\mathrm{RBCA}$ & $7 \mathrm{~d} ; 25^{\circ} \mathrm{C}$ \\
\hline (Faridi et al., 2017) & $\mathrm{x}$ & $\mathrm{x}$ & QuickTake ${ }^{\circledR} 30$ & $\begin{array}{l}\text { SDA with } \\
\text { chloramphenicol }\end{array}$ & $3-7 \mathrm{~d} ; 20-28^{\circ} \mathrm{C}$ \\
\hline (Fan et al., 2018) & $\mathrm{x}$ & - & $\begin{array}{l}\text { Adherent material applied in } \\
\text { floor surfaces }\end{array}$ & DG-18 & $5 \mathrm{~d} ; 25^{\circ} \mathrm{C}$ \\
\hline $\begin{array}{l}\text { (Madacussengua et } \\
\text { al., 2018) }\end{array}$ & $\mathrm{x}$ & $\mathrm{x}$ & Surface Air System & RBCA & $3-5 \mathrm{~d} ; 25^{\circ} \mathrm{C}$ \\
\hline
\end{tabular}

Note: $\mathrm{n} / \mathrm{d}:$ Not described. 
(MEA) (two with chloramphenicol added) and 2 Rose-Bengal Chloramphenicol Agar (RBCA). Faridi et al. (2017) used the QuickTake ${ }^{\circledR}$ 30 as air sampling device, with a spore trap cassette system, and Sabouraud Dextrose Agar (SDA) supplemented with chloramphenicol as culture medium. Other two studies used a different methodology, based on passive methods: adherent material applied in floor surfaces (Fan et al., 2017); and Electrostatic Dust Cloths (Karottki et al., 2015) using Dichloran Glycerol Agar (DG-18) as culture medium. The applied methodologies regarding temperature and incubation time are not equal through the selected works. For the impaction-based sampling studies, three (Madacussengua et al., 2019; Kim and Kim, 2007; Aguiar et al., 2014) describe similar conditions, with incubation periods from 3 to 5 days in a temperature between $20-25^{\circ} \mathrm{C}$. A slight difference could be observed in Cano et al. (2016) and Fan et al. (2018) with a duration and temperature of incubation around $4-5$ days and $25^{\circ} \mathrm{C}$, respectively. The other studies, Yilmaz et al. (2017), Faridi et al. (2017), Karottki et al. (2015) and Viegas et al. (2014), applied more incubation time for its samples: 5-7 days, and incubation temperatures between $25^{\circ} \mathrm{C}$ and $29^{\circ} \mathrm{C}$. Mendes et al. (2015) only presented the temperature of incubation, $25^{\circ} \mathrm{C}$.

Although the number of publications is scarce, it is interesting to notice the small divergence of reported results across Europe and Asia:

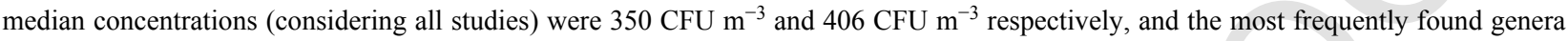
were Cladosporium sp., Penicillium sp. and Aspergillus sp. regardless the region. Knowing that weather conditions and geography-related vegetation (Jędryczka, 2014; Núñez et al., 2016) are the most accountable factors contributing to airborne fungi diversity, a wider heterogeneity in the results was expected.

Overall, the main findings reported in these publications were:

(1) Fungi species found in indoor air were similar to the ones found outdoor;

(2) Penicillium sp., Aspergillus sp. and Cladosporium sp. were the dominant genera of fungi both indoor and outdoor;

(3) Levels of fungi indoor were weakly but significantly correlated with the levels of PM2.5;

(4) Median concentration levels of indoor fungi exceed the median outdoor levels during winter season;

(5) Fungi median indoor concentrations were slightly above references in winter season, and peak values in both seasons (winter and summer) were concerning;

(6) Significant positive correlations were found between temperature and Aspergillus sp., Cladosporium sp. and Alternaria sp. levels;

(7) Correlation between circulating biomarkers, especially IL-6 and white blood cells counts, and fungal aerosols exposure among elderly subjects was found;

(8) Fungi levels in rural houses were higher than in urban houses.

No Health Authority or equivalent organization has already set specific limits for indoor air pollutants' levels regarding environments harboring particular groups of individuals, as children, the elderly, patients, and other immunologically vulnerable individuals. In addition, for fungi, the only existing regulation for indoor levels is specifically set for indoor environments as a measure of good indoor air quality, yet the values vary greatly between countries/entities. For instance: the European Confederation Commission recommends levels of fungi under $2000 \mathrm{CFU} \mathrm{m}^{-3}$; the World Health Organization (World Health Organization WHO, 2009), under $500 \mathrm{CFU} \mathrm{m}^{-3}$; the American Industrial Hygiene Association (AIHA) under $1000 \mathrm{CFU} \mathrm{m}^{-3}$ (EL-Morsy, 2006); the Turkish Standards Institute under $1000 \mathrm{CFU} \mathrm{m}^{-3}$ [TS 12281/Nisan 1997] (EL-Morsy, 2006); the Portuguese government sets the limit of indoor air fungi level at the level of concomitant outdoor air fungi level (Ordinance no 353-A/2013).

The levels of fungi found for elderly care centers varied between $5 \mathrm{CFU} \mathrm{m} \mathrm{m}^{-3}$ and $1343 \mathrm{CFU} \mathrm{m} \mathrm{m}^{-3}$ among the studies in review. Depending on the location, these levels could or not be acceptable. If the indoor concentrations of airborne fungi are higher that the outdoor concentration, the presence of indoor generative sources may be suspected. Nevertheless, from a health perspective the risk that fungi exposure poses is much more related to the susceptibility of the individuals rather than to general limits. As observed in one of the publications a correlation between circulating biomarkers of inflammation - IL-6 and white blood cells count - and fungi exposure could be established for a population of older people. Among older adults, asthma-related hospitalizations have already been associated with the presence of mold in the home environment. (Hsu et al., 2018). These data are suggestive that much more studies are needed to assess the influence of fungi in indoor air and older-people's health.

\section{Conclusion}

The growing number of aged populations is a consequence, among others, of the better health conditions that medical progress has enabled. These populations, despite their longevity, may present new challenges has their immune system, resistance, past diseases, and overall frailty may predispose them differently to otherwise non-threatening substances and contaminants. This still growing new reality coupled with changes in lifestyles and environment makes it a priority to fully assess the risk that indoor air contaminants exposure poses to these populations. Establishing safe exposure limits specifically considering these populations needs would result in improved health and quality of life, and a significant reduction in costs with healthcare.

\section{Appendix A Supplementary Material}

Supplementary data associated with this article can be found in the online version at doi:10.1016/B978-0-12-819990-9.21036-6. 


\section{References}

Aguiar, L., Mendes, A., Pereira, C., et al., 2014. Biological air contamination in elderly care centers: Geria project. Journal of Toxicology and Environmental Health A 77 (14-16), 944-958.

Allen, A.G., Miguel, A.H., 1995. Indoor organic and inorganic pollutants: In-situ formation and dry deposition in south-eastern Brazil. Atmospheric Environment 29, 3519-3526.

Almeida-Silva, M., Wolterbeek, H.T., Almeida, S.M., 2014. Elderly exposure to indoor air pollutants. Atmospheric Environment 85, 54-63.

Almeida-Silva, M., Almeida, S.M., Wolterbeek, H.T., 2014. Multi-elemental characterization of indoor aerosols in elderly care centers. Journal of Radioanalytical and Nuclear Chemistry 300, 679-684.

Almeida-Silva, M., Almeida, S.M., Pegas, P.N., et al., 2015. Exposure and dose assessment to particle components among an elderly population. Atmospheric Environment 102, 156-166.

Byčenkienè, S., Valuntaitè, V., Girgždienè, R., 2009. Simulation of indoor ozone concentration. Lithuanian Journal of Physics 49 (3), $335-339$.

Canha, N., Martinho, M., Almeida-Silva, M., et al., 2012. Indoor air quality in primary schools. International Journal of Environment and Pollution 50 (1/2/ 3/4), 396-410.

Canha, N., Almeida-Silva, M., Freitas, M.C., Almeida, S.M., 2012. Lichens as biomonitors at indoor environments of primary schools. Journal of Radioanalytical and Nuclear Chemistry 291 (1), 123-128.

Canha, N., Almeida, S.M., Freitas, M.C., Taubel, M., Hanninen, O., 2013. Winter ventilation rates at primary schools: Comparison between Portugal and Finland. Journal of Toxicology and Environmental Health A 76, 400-408.

Cano, M., Nogueira, S., Alves, M., et al., 2016. Avaliação da qualidade do ar em lares de idosos, 2013-2014: projeto GERIA. Observações - boletim epidemiológico instituto nacional de saúde dr. Ricardo jorge 4, 14-18.

Centers for Disease Control and Prevention (CDC), 2017. Mold and Dampness. Available at: https://www.cdc.gov/mold/dampness_facts.htm\#anchor_ 1512139804378. (accessed 22.11.19).

Douwes, J., Thorne, P., Pearce, N., Heederik, D., 2003. Bioaerosol health effects and exposure assessment: Progress and prospects. Annals of Occupational Hygiene 47, 187-200.

Eduard, W., Halstensen, A., 2009. Quantitative exposure assessment of organic dust. Scandinavian Journal of Work, Environment \& Health 7, $30-35$.

EL-Morsy, E.S.M., 2006. Preliminary survey of indoor and outdoor airborne microfungi at coastal buildings in Egypt. Aerobiologia 22 (3), 197-210.

Eurostat, 2014. Proportion of population aged 65 and over. Available at: http://ec.europa.eu/eurostat/tgm/table.do?tab=table\&init=1\&language $=$ en $\&$ pcode $=\operatorname{tps} 00028$ (accessed 03.09.15).

Eurostat, 2019. Euro Indicators. Accessed here: https://ec.europa.eu/eurostat/documents/2995521/10167388/6-16102019-BP-EN.pdf/ 8dabf16a-c28c-5ad3-10ca-e06845a36f69.

Fan, G., Xie, J., Yoshino, H., et al., 2018. Indoor environmental conditions in urban and rural homes with older people during heating season: a case in cold region, China. Energy and Buildings 167, 334-346.

Faridi, S., Naddafi, K., Kashani, H., et al., 2017. Bioaerosol exposure and circulating biomarkers in a panel of elderly subjects and healthy young adults. Science of The Total Environment 589-594, 380-389.

Fraga, S., Ramos, E., Martins, A., et al., 2008. Indoor air quality and respiratory symptoms in Porto schools. Revista Portuguesa de Pneumologia $14,487-507$.

Franck, U., Herbarth, O., Röder, S., et al., 2011. Respiratory effects of indoor particles in young children are size dependent. Science of the Total Environment 409, 1621-1631.

Fromme, H., Twardella, D., Dietrich, S., et al., 2007. Particulate matter in the indoor air of classrooms-exploratory results from Munich and surrounding area. Atmospheric Environment 41, 854-866.

GEP/MSSS, 2010. Carta Social - Rede de Serviços e Equipamentos, Lisbon, Ministério da Solidariedade e da Segurança Social.

Hsu, J., Chen, J., Mirabelli, M.C., 2018. Asthma morbidity, comorbidities, and modifiable factors among older adults. The Journal of Allergy and Clinical Immunology: In Practice 6 (1), 236-243.

Jędryczka, M., 2014. Aeromycology: studies of fungi in aeroplankton. Folia Biologica et Oecologica 10, 10-26.

Karottki, D., Spilak, M., Frederiksen, M., et al., 2015. Indoor and outdoor exposure to ultrafine, fine and microbiologically derived particulate matter related to cardiovascular and respiratory effects in a panel of elderly urban citizens. International Journal of Environmental Research and Public Health 12 , $1667-1686$.

Kim, K., Kim, C., 2007. Airborne microbiological characteristics in public buildings of Korea. Building and Environment 42, $2188-2196$.

Klepeis, N.E., Nelson, W.C., Ott, W.R., et al., 2001. The national human activity patter survey (NHAPS): A resource for assessing exposure to environmental pollutants. Journal of Exposure Analysis and Environmental Epidemiology 11, 231-252.

Kosonen, R., Tan, F., 2004. The effect of perceived indoor air quality on productivity loss. Energy and Buildings 36, 981-986.

Lee, S.C., Guo, H., Li, W.M., Chan, L.Y., 2002. Inter-comparison of air pollutant concentrations in different indoor environments in Hong Kong. Atmospheric Environment 36, 1929-1940.

Leech, J.A., Nelson, W.C., Burnett, R.T., Aaron, S., Raizenne, M.E., 2002. It's about time: A comparison of Canadian and American time-activity patterns. Journal of Exposure Analysis and Environmental Epidemiology 12, 427-432.

Madacussengua, O., Feliciano, M., Pereira, E., 2019. Qualidade do ar interior em ambiente geriátrico no Nordeste de Portugal. In: Proceedings of "Conferência Internacional de Ambiente em Língua Portuguesa", "XX Encontro da Rede de Estudos Ambientais de Países de Língua Portuguesa" and "XI Conferência Nacional do Ambiente, pp. 122-125. ISBN: 978-972-789-540-3.

Mendes, A., Bonassi, S., Aguiar, L., et al., 2015. Indoor air quality and thermal comfort in elderly care centres. Urban Climate 14, 486-501.

Mendes, A., Papoila, A.L., Carreiro-Martins, P., et al., 2016. The impact of indoor air quality and contaminants on respiratory health of older people living in long-term care residences in Porto. Age and Ageing 45, 136-142.

Núñez, A., Amo de Paz, G., Rastrojo, A., et al., 2016. Monitoring of airborne biological particles in outdoor atmosphere. Part 1: Importance, variability and ratios. International Microbiology 19, 1-13.

Ordinance 353-A/2013 de 4 de Dezembro. Available at: https://dre.pt/application/dir/pdf1sdip/2013/12/23501/0000200009.pdf.

Saliba, N.A., Atallah, M., Al-Kadamany, G., 2009. Levels and indoor-outdoor relationships of PM10 and soluble inorganic ions in Beirut, Lebanon. Atmospheric Research 92, 131-137.

Srikanth, P., Sudharsanam, S., Steinberg, R., 2008. Bio-aerosols in indoor environment: Composition, health effects and analysis. Indian Journal of Medical Microbiology 26 (4), 302-312.

United Nations (UN), 2012. Population Ageing and Development. United Nations, New York.

United Nations (UN), 2013. World Population Ageing 2013. United Nations, New York. 
Viegas, C., Alves, C., Carolino, E., Rosado, L., Santos, C.S., 2010. Prevalence of fungi in indoor air with reference to gymnasiums with swimming pools. Indoor and Built Environment 19 (5), 555-561.

Viegas, C., Almeida-Silva, M., Quintal Gomes, A., Wolterbeek, H.T., Almeida, S.M., 2014. Fungal contamination assessment in Portuguese Elderly Care Centers. Journal of Toxicology and Environmental Health, Part A - Current Issues 77 (1-3), 14-23.

Weschler, C.J., 2009. Changes in indoor pollutants since the 1950s. Atmospheric Environment 43, 153-169.

World Health Organization (WHO), 2009. Guidelines for Indoor Air Quality: Dampness and Mould. WHO Regional Office for Europe, Copenhagen.

World Health Organization (WHO), 2010. Guidelines for Indoor Air Quality and Selected Pollutants. WHO Regional Office for Europe, Copenhagen.

Yilmaz, O., Asan, A., Aydogdu, H., Sen, B., 2017. Airborne fungal diversity inside a nursing home in Edime, Turkey. Fresenius Environmental Bulletin 26 (12), 7025-7033.

Zhao, Y., Wang, S., Chen, G., et al., 2009. Microenvironmental time-activity patterns in Chongqing, China. Frontiers of Environmental Science \& Engineering in China 3 (2), 200-209.

\section{Further Reading}

Population Pyramid.net, 2019. Available in https://www.populationpyramid.net/. (accessed 28.11.19).

Wilson, W.E., Stanek, J., Han, H.S., et al., 2007. Use of electrical aerosol detector as an indicator of the surface area of fine particles deposited in the lung. Journal of the Air and Waste Management Association 57 (2), 211-220. 